\title{
Effect of Deficit Irrigation on Growth and Yield of Red Onion (Allium cepa) in Drip Irrigation System
}

\author{
R. M. Sujeewa ${ }^{1}$, T. Mikunthan ${ }^{2 *}$, S. Sayanthan ${ }^{1}$, Y. Thushyanthi ${ }^{1}$, M. Piraphaharan ${ }^{1}$
}

${ }^{1}$ Department of Agricultural Engineering, Faculty of Agriculture, University of Jaffna, Sri Lanka

${ }^{2}$ Professor, Department of Agricultural Engineering, Faculty of Agriculture, University of Jaffna, Sri Lanka

DOI: $10.36347 /$ sjavs.2020.v07i07.001

| Received: 12.06.2020 | Accepted: 20.06.2020 | Published: 09.07.2020

*Corresponding author: Mrs. T. Mikunthan

Abstract

Original Research Article

Improving water use efficiency is a vital strategy for addressing future water scarcity. Irrigation is a wide-ranging practice using every drop of water for crop production through suitable practices. Since irrigation plays a key role in global water availability by impacting water productivity, a field experiment was conducted in $\mathrm{DL}_{3}$ agro ecological region during the yala season of 2018 using drip and basin irrigation methods to evaluate the effect of deficit irrigation practices on growth, yield and water use efficiency of onion. Four treatments; water application through drip irrigation at $150 \%, 100 \%$ and $70 \%$ of crop water requirement and basin irrigation as control were designed. Water application at $100 \%$ of crop water requirement gave significantly higher onion yield as compared to $70 \%$ of crop water requirement and basin irrigation treatment. Also yield from $70 \%$ of water application and basin was not significantly different. The onion irrigated at $100 \%$ recorded $22.3 \%$ of increase in yield over basin method of irrigation. But, irrigation water use efficiency was found highest with drip irrigation at $70 \%$ of water application and lowest with basin irrigation. The amount of water saved at $150 \%, 100 \%$ and $70 \%$ under drip method was $13.8 \%, 31.12 \%$ and $50.8 \%$ respectively over basin method and this would be sufficient to irrigate additional area of onion crop earning better economic returns as compared to basin irrigation method. When consider the irrigation water use efficiency $70 \%$ of water application was the best irrigation practice compared to basin irrigation. Hence, the study suggests farmers in the dry region having limited amount of water for irrigation, should adopt drip method with combination of deficit irrigation rather than practice of basin irrigation methods.

Keywords: Drip irrigation, Deficit irrigation, water use efficiency, onion, yield.

Copyright @ 2020: This is an open-access article distributed under the terms of the Creative Commons Attribution license which permits unrestricted use, distribution, and reproduction in any medium for non-commercial use (NonCommercial, or CC-BY-NC) provided the original author and source are credited.

\section{INTRODUCTION}

Declining of water availability and quality affects industries, municipalities, agricultural practices, recreational users and ultimately the ecosystems. According to the statement of FAO, with rapid growing world population, global agricultural production has to be increased by $60 \%$ to meet the projected demand by 2025. Irrigated agriculture is the largest water consuming sector. Therefore the food security for future generation is in a shake with an increasing population and less water availability for agricultural production [1]. Irrigation management should be shifted from emphasizing production per unit area to the maximizing production per unit of water consumed due the insufficient water supply for irrigation than the expectation in present and future [2].

Irrigated agriculture sector in Sri Lanka uses almost $85 \%$ to $90 \%$ of water, in terms of volume [3]. Water needs is constantly competing with the domestic, industrial and environmental uses for a scarce water supply [4]. Northern region of Sri Lanka practices excess water application in the form of basin irrigation or flooded irrigation with the focus of highest yield. Efficient water management through micro irrigation is best practice to conserve the water since the region has a continuous long history of water crisis.

Micro irrigation technology has several irrigation methods to accomplish the optimum amount of water to the crops with saving water. One of the method is sprinkler irrigation method than the furrow irrigation [5]. When compared to drip irrigation, the sprinkler irrigation system usually wet the above ground parts of the plant. The entire soil surface is saturated and mostly stays wet long after irrigation is completed. Flood type irrigation system consume huge amount of water and the area between crop and rows remains dry and receives moisture only from incidental rainfall [6]. 
Thus the drip irrigation is introduced primarily to save water and increase the water use efficiency in agriculture. It has potential to use scarce water resources more efficiently to produce crops as water can be delivered specifically to the root zones rather than the irrigating whole field surface as with other methods [7]. The on-farm irrigation efficiency of properly designed and managed drip irrigation system is estimated to be about $90 \%$, while the same is only about 35 to 40 percent for surface method of irrigation [8]. The experience from many countries showed that farmers who shifted from surface irrigation to drip irrigation they can cut down their water use by $30 \%$ to $60 \%$ at the same time with increasing the yield [9]. Further comparison of drip and surface method, drip method saved $56.4 \%$ water and gave $22 \%$ higher yield than the surface method of irrigation [7].

Another way to address the issues of water shortage is through development of new irrigation scheduling techniques such as deficit irrigation. Significant water savings can be achieved by deliberately stressing plants to a certain profitable level. If irrigation rates are reduced at predetermined developmental stages where deficits would not severely impact productivity, it is called regulated deficit irrigation [10]. Because of increasing water scarcity, it is expected that deficit irrigation would be adopted for a wide variety of crops with target deficit level. Increased water stress in agriculture can manage with implementation of innovative technologies such as automated microcontroller drip irrigation system.

Onion (Allium cepa) is one of the most important commercial crop grown mainly in Northern region of Sri Lanka consuming huge amount of water for the cultivation. According to the statistics of Sri Lanka, total national requirement of onion is 100,000 $\mathrm{mt} /$ year, but production is only $60,000 \mathrm{mt} /$ year [11]. Hence the main objective of this study was to find out minimum moisture level which will facilitate to give maximum yield, and to compare water use efficiency and increasing yield of onion with deficit drip irrigation compared to basin irrigation method.

\section{MATERIALS AND METHOD \\ Description of the study area}

The study was conducted at the Kilinochchi; located under $\mathrm{DL}_{3}$ agro ecological region in Northern Sri Lanka during the yala season. The mean annual rainfall of the area was $1040 \mathrm{~mm}$ to $1250 \mathrm{~mm}$ and temperature was $28^{\circ} \mathrm{C}$ to $34^{\circ} \mathrm{C}$.

\section{Investigation of Existing Field Condition}

Discharge rate of the emitters were measured. Two emitters from each replicate were selected randomly in order to measure the discharge rate of emitters. Catch cans were placed under selected emitters and quantity of water in each can was measured after 3 minutes. This measurement was repeated for three times. According to the reading the uniformity of the emitters was ensured. Emission uniformity co-efficient was calculated according to the following equation [12]

$$
E u=\frac{Q n}{Q a}
$$

In Which

$$
\begin{aligned}
& \text { Eu = Emission uniformity co-efficient } \\
& \mathrm{Qn}=\text { Minimum emitter discharge } \\
& \mathrm{Qa}=\text { Average discharge }
\end{aligned}
$$

\section{Development of Automated Irrigation Model}

Micro controller, sensors, data logger, GSM module display and Solenoid valves were used in such way to design crop micro environment device. For the sensing process Arduino UNO, Soil Moisture sensors (YL-69) and Temperature and RH sensor (DHT-11) were used. According to the planned test the automated irrigation tool along with the drip system facilitated the irrigation procedure.

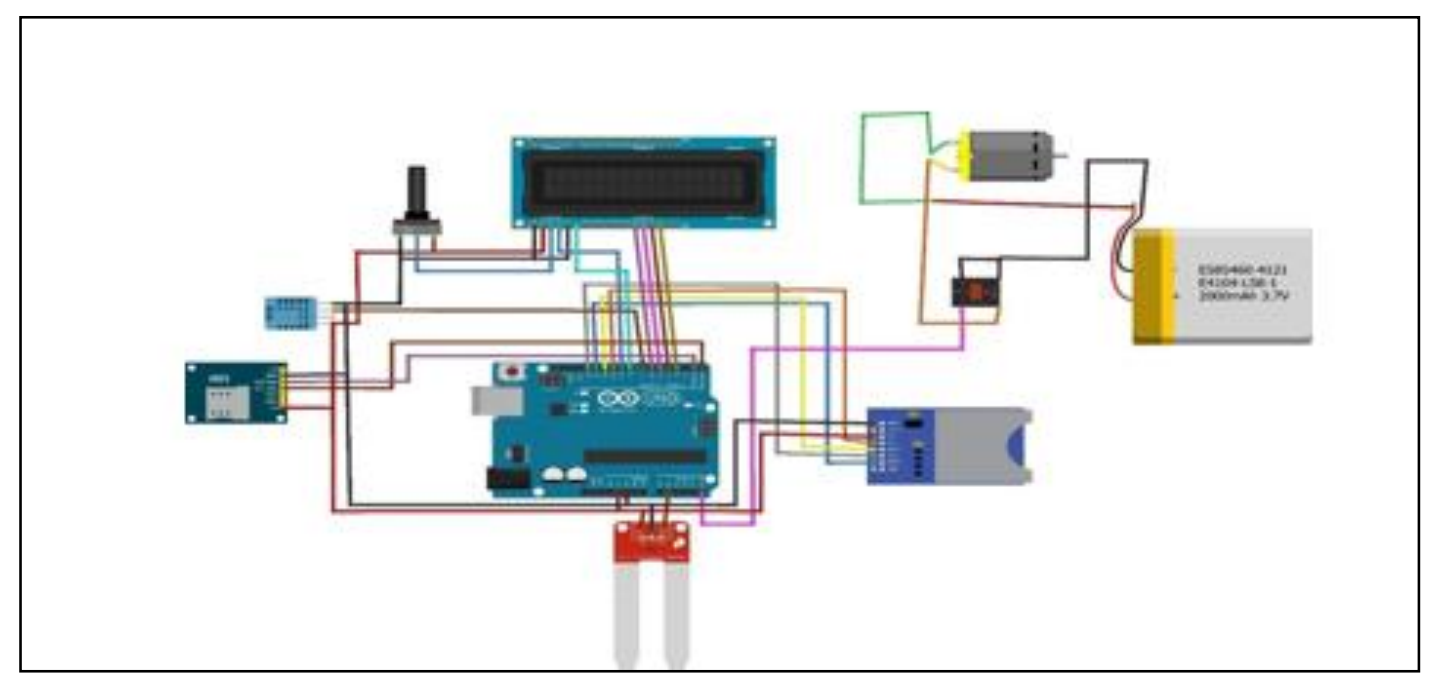




\section{Experimental Procedure}

Soil parameters such as bulk density, particle density, field capacity and infiltration rate of the soil were estimated. Permanent wilting point of the soil is taken from the literature [13]. The experiment was laid in randomized design having four treatments with three replicates. Cultural management practices were done according to the recommendation of Department of agriculture except irrigation water. Onion bulbs were planted after pretreatment. The distance between plots, rows and plant were $0.5 \mathrm{~m}, 10 \mathrm{~cm}$ and $10 \mathrm{~cm}$ respectively. Each plot has four rows and 20 plants were in each row. Water was applied at three levels of irrigation as $70 \%$ (T1), 100\% (T2) and 150\% (T3) of crop water requirement through drip irrigation, while the basin as farmers practice at irrigation level of $150 \%$ (T4) crop water requirement was used [14, 15]. Treatments were started after initial stage of the onion crop. Data was subjected to statistical analysis using SAS software and descriptive statistics. Analysis of variance (ANOVA) was performed to evaluate the statistical effect of the different irrigation treatments on growth and yield and Water Use Efficiency. Occurrence of rainfall during the study period was observed and no any rainfall durin the period.

\section{Growth Parameters}

The five plants were randomly selected in each plot and data were collected at four days interval.

Plant height was measured by using a meter scale. And neck thickness and bulb diameter were measured using Vernier caliper at the narrowest point of the bulb and widest point of the bulb respectively. Total numbers of leaves were counted from selected plants.

\section{Yield Parameters}

Center rows of the plot were selected to avoid boarder effect for the estimation of bulb weight. The average weight of each onion bulb was determined with total number of harvested bulb weight and number of harvested bulb.

\section{Water saving and water use efficiency of onion}

The water use efficiency was calculated by dividing harvested yield in $\mathrm{Kg}$ by unit volume of water $\left(\mathrm{Kg} / \mathrm{m}^{3}\right)$. Irrigation water use efficiency (IWUE) [16] is determined as

$$
I W U E=\frac{\mathrm{Ya}}{\mathrm{IW}}
$$

Where,

$$
\begin{aligned}
& \mathrm{Ya}=\text { yield }(\mathrm{Kg} / \mathrm{ha}) \\
& \mathrm{IW}=\text { irrigation water applied }\left(\mathrm{m}^{3} / \mathrm{ha}\right)
\end{aligned}
$$

\section{RESULTS AND DISCUSSION \\ Investigation of existing field condition}

The bulk density and particle density of the soil were $1.34 \mathrm{~g} / \mathrm{cm}^{3}$ and $2.6 \mathrm{~g} / \mathrm{cm}^{3}$ respectively. Moisture content at field capacity was estimated as $26 \%$ on volumetric basis. According to the literature, permanent wilting point is taken as $10 \%$ [13]. Average infiltration rate of the soil was $27.2 \mathrm{~mm} / \mathrm{h}$. The discharge rate of the emitter was set less than the infiltration rate of the soil. Overall average discharge rate of the emitter was $3.6 \mathrm{l} / \mathrm{h}$. The estimated emission uniformity co efficient was $88.88 \%$.

\section{Growth parameters of the onion}

Table 1 shows the average plant height and variation of number of leaves in different level of irrigation. There were significant $(\mathrm{p}<0.05)$ differences among the levels of irrigation water and irrigation methods on onion growth parameters. It is observed that the plant height was varying with the treatments $\mathrm{T} 1$ to T4. The minimum plant height $33 \mathrm{~cm}$ was observed in treatment $\mathrm{T} 1$, whereas the maximum plant height was observed as $40.6 \mathrm{~cm}$ in treatment T3. The $70 \%$ deficit irrigation, plant height was reduced from middle of the development stage. According to the literature, onion plant will get more stress at vegetative and bulb formation stages [17]. The number of leaves was not significantly $(\mathrm{p}<0.05)$ different within the treatments, because after development stage and at the bulbing stage that production of new leaves might probably cease. But observation was that the number of leaves positively and significantly correlated with bulb yield [18].

Table-1: Plant height and no of leaves variation in different treatment

\begin{tabular}{|l|l|l|l|l|l|l|l|l|}
\hline \multirow{2}{*}{ days after development stage } & \multicolumn{4}{|l|}{ plant height $(\mathbf{c m})$} & \multicolumn{3}{l|}{ number of leaves } \\
\cline { 2 - 9 } & T1 & T2 & T3 & T4 & T1 & T2 & T3 & T4 \\
\hline 4 & $28.14^{\mathrm{ab}}$ & $28.63^{\mathrm{a}}$ & $28.51^{\mathrm{a}}$ & $28.04^{\mathrm{ab}}$ & 21.47 & 22.33 & 23.06 & 23.13 \\
\hline 8 & $28.2^{\mathrm{b}}$ & $29.39^{\mathrm{a}}$ & $29.38^{\mathrm{a}}$ & $28.8^{\mathrm{ab}}$ & 23.13 & 23.8 & 25.27 & 23.13 \\
\hline 12 & $29^{\mathrm{ab}}$ & $29.92^{\mathrm{ab}}$ & $30.46^{\mathrm{a}}$ & $29.63^{\mathrm{ab}}$ & 25.06 & 28.13 & 28.27 & 27.68 \\
\hline 16 & $29.75^{\mathrm{d}}$ & $31.15^{\mathrm{a}}$ & $31.53^{\mathrm{a}}$ & $30.44^{\mathrm{c}}$ & 28.53 & 30.93 & 30.6 & 29.98 \\
\hline 20 & $30^{\mathrm{d}}$ & $32.2^{\mathrm{ab}}$ & $32.85^{\mathrm{a}}$ & $31.69^{\mathrm{c}}$ & 29.6 & 30.53 & 30.9 & 30.33 \\
\hline 24 & $31.78^{\mathrm{c}}$ & $34.6^{\mathrm{ab}}$ & $34.8^{\mathrm{a}}$ & $32^{\mathrm{c}}$ & 31.93 & 32.5 & 32.68 & 31.28 \\
\hline 28 & $32.6^{\mathrm{c}}$ & $36.7^{\mathrm{ab}}$ & $36.9^{\mathrm{a}}$ & $32.72^{\mathrm{bc}}$ & 33.67 & 34.8 & 34.8 & 34.73 \\
\hline 32 & $33^{\mathrm{c}}$ & $40.5^{\mathrm{ab}}$ & $40.6^{\mathrm{a}}$ & $33.3^{\mathrm{bc}}$ & 35.13 & 36.1 & 36.13 & 35.26 \\
\hline
\end{tabular}

Each values followed by the same letter are not significantly different at $p=0.05$. 
The neck thickness was significantly different with treatments and shown in Table-2. There were significant variations at treatment levels. The treatment T3 was shown highest performance with significant value from the development stage but at the end there were no significant variation between $\mathrm{T} 2$ and $\mathrm{T} 3$ as 1.19 $\mathrm{cm}$ and $1.2 \mathrm{~cm}$ respectively. When compared to the deficit irrigation (T1), no significant variation was observed with T4 as lowest value of $0.81 \mathrm{~cm}$ and 0.82 cm respectively.

Table-2: Neck thickness variation at different irrigation levels

\begin{tabular}{|l|l|l|l|l|}
\hline \multicolumn{5}{|l|}{ Neck thickness (cm) } \\
\hline days after development stage & T1 & T2 & T3 & T4 \\
\hline 4 & $0.42^{\mathrm{b}}$ & $0.43^{\mathrm{b}}$ & $0.47^{\mathrm{a}}$ & $0.44^{\mathrm{b}}$ \\
\hline 8 & $0.49^{\mathrm{c}}$ & $0.50^{\mathrm{bc}}$ & $0.54^{\mathrm{a}}$ & $0.54^{\mathrm{b}}$ \\
\hline 12 & $0.54^{\mathrm{c}}$ & $0.56^{\mathrm{b}}$ & $0.58^{\mathrm{a}}$ & $0.56^{\mathrm{b}}$ \\
\hline 16 & $0.58^{\mathrm{c}}$ & $0.62^{\mathrm{bc}}$ & $0.65^{\mathrm{a}}$ & $0.64^{\mathrm{b}}$ \\
\hline 20 & $0.66^{\mathrm{c}}$ & $0.7^{\mathrm{bc}}$ & $0.73^{\mathrm{a}}$ & $0.72^{\mathrm{b}}$ \\
\hline 24 & $0.71^{\mathrm{c}}$ & $0.79^{\mathrm{b}}$ & $0.81^{\mathrm{a}}$ & $0.79^{\mathrm{b}}$ \\
\hline 28 & $0.8^{\mathrm{b}}$ & $0.89^{\mathrm{a}}$ & $0.9^{\mathrm{a}}$ & $0.87^{\mathrm{b}}$ \\
\hline 32 & $0.81^{\mathrm{b}}$ & $1.19^{\mathrm{a}}$ & $1.2^{\mathrm{a}}$ & $0.82^{\mathrm{b}}$ \\
\hline
\end{tabular}

Each values followed by the same letter are not significantly different at $p=0.05$.

Figure-1 shows the variation of bulb diameter of different treatment. The level of irrigation water affects the bulb diameter. The lowest value were shown in T1 $(2.65 \mathrm{~cm})$ and T4 $(2.7 \mathrm{~cm})$ and the highest values were shown in T2 $(3.32 \mathrm{~cm})$ and T4 $(3.42 \mathrm{~cm})$. Result was reported that the bulb diameter was increased when the irrigation water or soil moisture increased up to a certain limit [19]. Thus statically treatment T2 and T3 were significantly differed compared to treatment $\mathrm{T} 1$ and $\mathrm{T} 4$

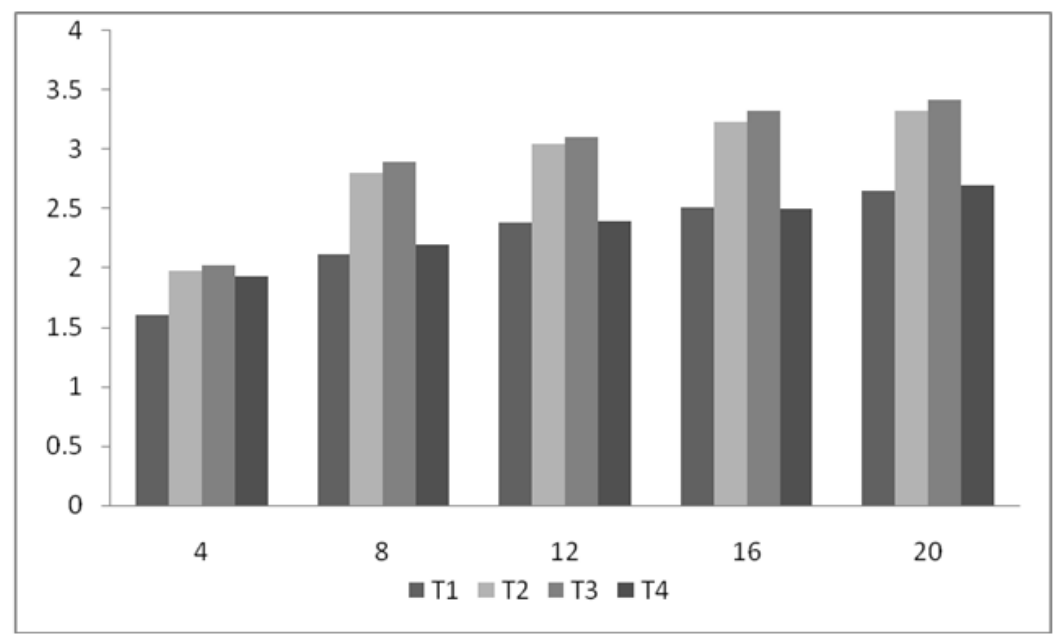

Fig-1: Bulb diameter $(\mathrm{cm})$ variation at different moisture levels

\section{Yield parameters of onion}

There were significant $(p<0.05)$ differences among irrigation methods and levels of irrigation water applications on onion bulb yield (Figure-2). The result indicated that basin method of irrigation under full irrigation resulted in low yield of (27.5 t/ha) as compared to that obtained under drip irrigation (35.8 $\mathrm{t} / \mathrm{ha})$ and it was significantly different $(\mathrm{p}<0.05)$. Based on the results, drip irrigation treatments (T2 and T3) registered $23.2 \%, 22.3 \%$ increase in yield respectively as compared to basin irrigation (T4). However, decreasing the applied water by $30 \%$ of crop water requirement led to yield reduction of onion $23.7 \%$ compared to full irrigation under drip method which is close to yield reduction by basin $(23.2 \%)$, statistically there was no any significant different between deficit (T1) and the basin (T4). Therefore, the study indicated that, even if $30 \%$ less quantity of water was supplied through drip irrigation (T1), only $0.5 \%$ yield reduction of onion was obtained as compared to surface irrigation. 


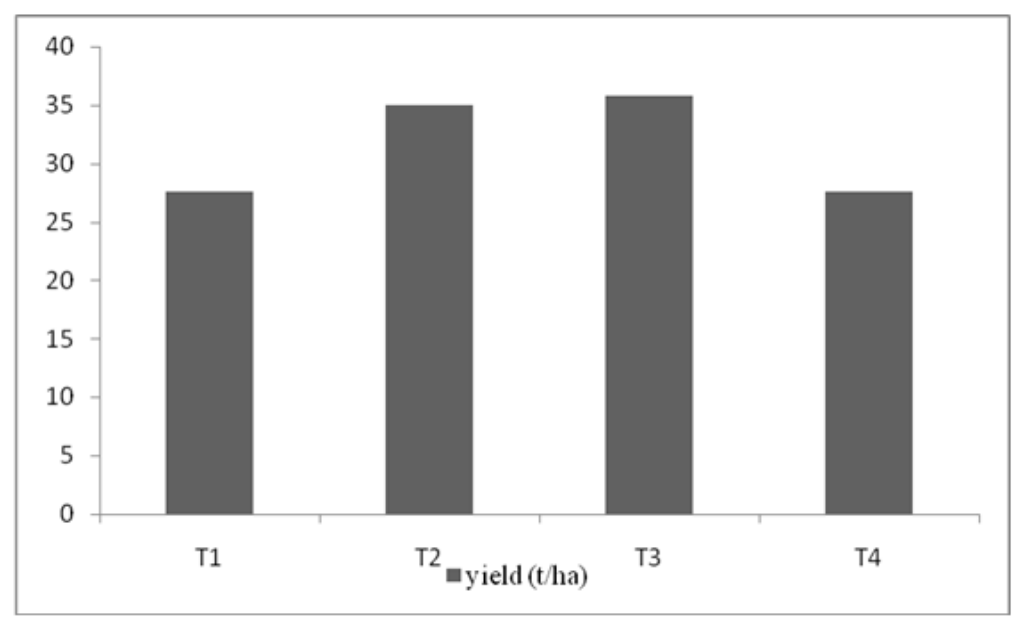

Fig-2: Effect of deficit irrigation and irrigation method on yield (t/ha) of onion

In case of water application, $100 \%$ and $70 \%$ water application saved $31.12 \%$ and $50.8 \%$ water respectively as compared to basin method (Table-3). The low yield by basin irrigation might be due to less availability of nutrients for crop growth and with high weed infestation between the crops.

These findings were supported with the study [20] reporting that about $15 \%$ higher fresh onion yields under drip irrigation and used at least $57 \%$ less water than the surface irrigation system. Correspondingly, drip irrigation system could increase the capsicum yield up to an extent of $57 \%$ over surface irrigation method with the same amount of water [19]. Several studies on the performance of drip irrigation method on different crop types reported that drip irrigation method gave more yield as compared to that of basin irrigation method with the same quantity of water used [7, 9, 21]. Also the finding of deficit irrigation under drip method was gave the high yield when compared to basin irrigation. Higher yield of $16.2 \%$ was obtained by drip with $20 \%$ of deficit irrigation, whereas $80 \%$ and $60 \%$ of deficit water application saved $43.5 \%$ and $57.6 \%$ water respectively as compared to surface irrigation method [16].

\begin{abstract}
Water Use Efficiency
Water use efficiency was significantly influenced by irrigation levels and irrigation method (Table-3). Seeing full irrigation application, higher mean value of irrigation water use efficiency was observed under drip method with mean value of 9.28 $\mathrm{kg} / \mathrm{m}^{3}$ which was $48.5 \%$ higher than that was obtained in basin method $\left(4.77 \mathrm{~kg} / \mathrm{m}^{3}\right)$ and it was significantly different $(p<0.05)$. This might be due to the even distribution of moisture in the effective root zone of onion crop in the soil profile under drip irrigation method and subsequently minimal runoff, evaporation and percolation losses. Furthermore, applying $70 \%$ water under drip irrigation method improved irrigation water use efficiency by $37 \%$, with water saving of $280.1 \mathrm{~mm}$ which is sufficient to irrigate further area of onion crop in which this earns well economic returns as compared to that of basin irrigation method.
\end{abstract}

Table-3: Increasing yield, yield reduction, water saved amount and irrigation water use efficiency in different treatments under irrigation methods

\begin{tabular}{|c|c|c|c|c|c|c|c|}
\hline \multirow[t]{2}{*}{ Irrigation method } & \multirow[t]{2}{*}{ Treatment } & \multicolumn{2}{|c|}{ Increasing yield } & \multicolumn{2}{|c|}{ Yield reduction } & \multirow[t]{2}{*}{ WS \% } & \multirow{2}{*}{$\begin{array}{l}\text { IWUE } \\
\mathrm{Kg} / \mathrm{m}^{3}\end{array}$} \\
\hline & & t/ha & $\%$ & t/ha & $\%$ & & \\
\hline Basin & $\mathrm{T} 4(150 \%)$ & 0 & 0 & 8.3 & 23.2 & 0 & 4.77 \\
\hline \multirow[t]{3}{*}{ Drip irrigation } & T3 $(150 \%)$ & 8.3 & 23.2 & 0 & - & 13.8 & 7.23 \\
\hline & $\mathrm{T} 2(100 \%)$ & 7.9 & 22.3 & 0.4 & 1.1 & 31.12 & 8.92 \\
\hline & $\mathrm{T} 1(70 \%)$ & -0.33 & -1.21 & 8.63 & 23.7 & 50.8 & 9.28 \\
\hline
\end{tabular}

Similarly, drip irrigation saved $50.8 \%, 31.12 \%$ and $13.8 \%$ water, under $70 \%, 100 \%$ and $150 \%$ water application respectively, as compared to basin irrigation as existing in Table 3. Irrigation use efficiency of onion obtained under drip irrigation system ranged from 17.5 to $25.2 \mathrm{~kg} / \mathrm{m}^{3}$ while using at least $44 \%$ less water as compared to that of basin system ranged from 4.2 to 6.2 $\mathrm{kg} / \mathrm{m}^{3}$ [22]. Likewise, the irrigation efficiency under drip irrigation increased by $29 \%$ and saved $20.8 \%$ amount of irrigation water in comparison with surface irrigated potato [23]. Similar trend has been reported in water use efficiency of various crops in comparison of drip with deficit and basin irrigation methods for capsicum [19], pepper [24], tomato [7] and maize crop [25]. Deficit irrigation, by reducing irrigation water use, can aid in coping with situations where supply is restricted. In field crops, a well-designed deficit irrigation regime can optimize water productivity over an area [26]. 
R. M. Sujeewa et al., Sch J Agric Vet Sci, July, 2020; 7(7): 144-150

\section{CONCLUSION AND RECOMMENDATION}

Results revealed that the deficit irrigation under drip method is one of the irrigation management strategy which could contribute for water saving, increase yield and water use efficiency in the water scarcity area. Drip irrigation method saved $50.1 \%$ and $13.8 \%$ water, and gives $22.3 \%$ and $23.2 \%$ more yields under $100 \%$ and $150 \%$ water application respectively, as compared to that of basin irrigation method. In addition, higher irrigation water use efficiency of 9.28 $\mathrm{kg} / \mathrm{m}^{3}$ was obtained at $70 \%$ water application in deficit irrigation under drip method which is $48.5 \%$ higher than the low irrigation water use efficiency of 4.77 $\mathrm{kg} / \mathrm{m}^{3}$ obtained under basin method. Also the yield reduction was no significant through deficit (23.7\%) and basin $(23.2 \%)$. The deficit irrigation with drip method could be a best one for onion cultivation in water scarcity area over surface irrigation method. In addition, considering the high yield $(22.3 \%)$ with water saving $(31.12 \%)$, the application of water at $100 \%$ could be suggested for the farmers. It was also observed that, the amount of saved water would be sufficient to irrigate additional area of onion crop with the drip irrigation method.

\section{REFERENCES}

1. Zwart SJ, Bastiaanssen WG. Review of measured crop water productivity values for irrigated wheat, rice, cotton and maize. Agricultural water management. 2004 Sep 15;69(2):115-33.

2. Fereres E, Soriano MA. Deficit irrigation for reducing agricultural water use. Journal of experimental botany. 2007 Jan 1;58(2):147-59.

3. Zainudeen MY. Water resources development/management for agriculture in Sri Lanka; Past and future. Engineer: Journal of the Institution of Engineers, Sri Lanka. 2007 Jan 24;40(1): 7-16.

4. Gerten D, Heinke J, Hoff H, Biemans H, Fader M, Waha K. Global water availability and requirements for future food production. Journal of hydrometeorology. 2011 Oct;12(5):885-99.

5. Thushyanthy M, Srivatharasan T. Yield performance of red onion under different irrigation management in Jaffna peninsula. Journal of science Eastern University of Sri Lana, 2008; 5(1):65-74.

6. Swamy DK, Rajesh G, Pooja MJ, Krishna AR. Microcontroller based drip irrigation system. International Journal of Emerging Science and Engineering. 2013 Dec;1(6):1-4.

7. Tagar A, Chandio FA, Mari IA, Wagan B. Comparative study of drip and furrow irrigation methods at farmer's field in Umarkot. World Academy of Science, Engineering and Technology. 2012 Sep 25;69:863-7.

8. Narayanamoorthy A. Drip and Sprinkler Irrigation in India: Benefits, Potential and Future Directions, in: Strategic Analyses of the National River Linking Project (NRLP) of India, Series 1, India's
Water Future: Scenarios and Issues, edited by: Upali, A. and Amarasinghe, T. S. A. R. P. S. M., International Water Management Institute, Colombo, Sri Lanka, 2009:253-266.

9. Enchalew B, Gebre SL, Rabo M, Hindaye B, Kedir M, Musa Y, Shafi A. Effect of deficit irrigation on water productivity of onion (Allium cepal.) under drip irrigation. Irrigat Drainage Sys Eng. 2016;5(172):2.

10. Chalmers DJ, Mitchel PD, Van Heek L. Control of peach tree growth and productivity by regulated water supply, tree density, and summer pruning. Journal of American Society of Horticultural Science. 1981; 106(3):307-312.

11. Department of Census and Statistics. Sri Lanka Onion seed production and crop husbandry (2015). Field crops research and development institute. Department of Agriculture.

12. Sivanappan RK, Padmakumari O, Kumar V. Drip Irrigation, Keerthi Publishing House, Coimbatore, India. 1987.

13. Joshua WD. Physical properties of soil as related to irrigation and water management. InProceedings of National seminar on water management and control at the farm level FAO/Sri Lanka 1973 Jun (pp. 18-23).

14. Bossie M, Tilahun K, Hordofa T. Crop coefficient and evaptranspiration of onion at Awash Melkassa, Central Rift Valley of Ethiopia. Irrigation and Drainage Systems. 2009 Feb 1;23(1):1-10.

15. Allen RG, Pereira LS, Raes D, Smith M. Crop evapotranspiration-Guidelines for computing crop water requirements-FAO Irrigation and drainage paper 56. Fao, Rome. 1998;300(9):D05109.

16. Tefery G. Effect of drip and surface irrigation methods on yield and water use efficiency of onion (Allium cepa L.) under semi-arid condition of Northern Ethiopia. Journal of biology, Agriculture and Healthcare, 2015; 5(14):88-94.

17. Bhagyawant RG, Gorantiwar SD, Dahiwalkar SD. Effect of deficit irrigation on crop growth, yield and quality of onion under surface irrigation. Journal of Agriculture and Environmental science, 2015; 15(8):1672-1678.

18. Adjei-Twum DC. The influence of bulb size and bulb cutting on the growth and yield of shallots (Allium cepa var. Aggregatum G. Don.) in Ghana. Journal of Horticultural Science. 1980 Jan 1;55(2):139-43.

19. Paul JC, Mishra JN, Pradhan PL, Panigrahi B. Effect of drip and surface irrigation on yield, water-use-efficiency and economics of capsicum (c apsicum annum 1.) Grown under mulch and non mulch conditions in eastern coastal India. European Journal of Sustainable Development. 2013 Feb 1;2(1):99-108.

20. Enciso J, Jifon J, Anciso J, Ribera L. Productivity of onions using subsurface drip irrigation versus furrow irrigation systems with an internet based 
irrigation scheduling program. International Journal of Agronomy. 2015 Jan 1;2015.

21. Sammis TW. Comparison of Sprinkler, Trickle, Subsurface, and Furrow Irrigation Methods for Row Crops 1. Agronomy Journal. 1980 Sep;72(5):701-4.

22. Enciso J, Jifon J, Anciso J, Ribera L. Productivity of onions using subsurface drip irrigation versus furrow irrigation systems with an internet based irrigation scheduling program. International Journal of Agronomy. 2015 Jan 1;2015.

23. Nagaz K, Toumi I, Masmoudi MM, Mechlia NB. Comparative effects of drip and furrow Irrigation with saline water on the yield and water use efficiency of potato (Solanum tuberosum L.) in arid conditions of Tunisia. Agricultural Journal. 2008;3(4):272-7.
24. Nagaz K, Masmoudi MM, Mechlia NB. Effects of deficit drip-irrigation scheduling regimes with saline water on pepper yield, water productivity and soil salinity under arid conditions of Tunisia. Journal of Agriculture and Environment for International Development (JAEID). 2012 Dec 20;106(2):85-103.

25. Ayana M. Deficit irrigation practices as alternative means of improving water use efficiencies in irrigated agriculture: Case study of maize crop at Arba Minch, Ethiopia. African Journal of Agricultural Research. 2011 Jan 18;6(2):226-35.

26. Fereres E, Soriano MA. Deficit irrigation for reducing agricultural water use. Journal of experimental botany. 2007 Jan 1;58(2):147-59. 